\title{
Large scaled analysis of hepatitis B virus (HBV) DNA integration in HBV related hepatocellular carcinomas
}

\author{
Y Murakami, K Saigo, H Takashima, M Minami, T Okanoue, C Bréchot, P Paterlini-Bréchot
}

Gut 2005;54:1162-1168. doi: 10.1136/gut.2004.054452

See end of article for authors' affiliations

Correspondence to: Dr Y Murakami, Department of

Gastroenterology, Fukui

National Hospital, 33-1

Sakuragaoka, Tsuruga,

Fukui 914-0195, Japan;

ymurakami@

virus.kyoto-u.ac.jp

Revised version received 11 August 2004

Accepted for publication

9 November 2004
Background and aims: Hepatitis B virus (HBV) DNA integration into or close to cellular genes is frequently detected in HBV positive hepatocellular carcinomas (HCC). We have previously shown that viral integration can lead to aberrant target gene transcription. In this study, we attempted to investigate common pathways to hepatocarcinogenesis.

Methods: By using a modified Alu-polymerase chain reaction approach, we analysed $50 \mathrm{HCC}$ along with 10 previously published cases.

Results: Sixty eight cellular flanking sequences (seven repetitive or unidentified sequences, 42 cellular genes, and 19 sequences potentially coding for unknown proteins) were obtained. Fifteen cancer related genes and 25 cellular genes were identified. HBV integration recurrently targeted the human telomerase reverse transcriptase gene (three cases) and genes belonging to distinct pathways: calcium signalling related genes, 60s ribosomal protein encoding genes, and platelet derived growth factor and mixed lineage leukaemia encoding genes. Two tumour suppressor genes and five genes involved in the control of apoptosis were also found at the integration site. The viral insertion site was distributed over all chromosomes except $13, \mathrm{X}$, and $\mathrm{Y}$.

Conclusions: In $61 / 68$ (89.7\%) cases, HBV DNA was integrated into cellular genes potentially providing cell growth advantage. Identification of recurrent viral integration sites into genes of the same family allows recognition of common cell signalling pathways activated in hepatocarcinogenesis.
$\mathrm{V}$ ral insertional mutagenesis is a powerful tool for identifying cancer related genes. In fact, cellular genes have been successfully identified using this method in animal models. ${ }^{1}$ In the majority of hepatocellular carcinomas (HCCs) developed in chronic hepatitis B virus (HBV) carriers, the viral genome is clonally integrated into the host chromosomal DNA. ${ }^{2-4}$ In some cases where detailed molecular studies have been performed, integration of the virus into the host genome was found to lead to novel fusion transcripts and/or local genomic instability, resulting in secondary deletions, rearrangements, duplications, or inversions of the host and/or viral genomic sequences. ${ }^{5-8}$ It is also generally accepted that the HBV genome has, in itself, some oncogenic activities. HBV encodes HBX and preS2/S truncated proteins which may have transforming activity ${ }^{2}$ and may interfere with DNA repair. ${ }^{9}$ Chronic infection by woodchuck hepatitis virus (WHV) was used as an animal model of chronic liver disease followed by liver carcinogenesis. In humans, the lifetime risk of cancer for a HBV chronically infected person is approximately $10-25 \%$ while in woodchucks the lifetime risk is approximately $100 \%{ }^{10}$ The human papillomavirus 18 (HPV) also recurrently integrates in the vicinity of the c-myc gene and the relationship between HPV18 integration and development of cervical cancer has been demonstrated. ${ }^{11}$ In almost all cases examined so far, integration of WHV activates transcription at the $\mathrm{N}$-myc2 locus. In the few cases where $\mathrm{N}$-myc2 was not transcribed, WHV integration was found at the c-myc locus or $\mathrm{N}$-mycl locus. ${ }^{12} 13$ Accordingly, many researchers have tried in the past to investigate the relationship between viral integration and hepatocarcinogenesis; however, further technological advances were needed to isolate the viral/cellular junctions on a large scale and elucidate this issue. We have previously identified 21 cellular sequences as targets of HBV-DNA integration from 18 HCC using the HBV $X$ sequence as a genetic tag. ${ }^{14}{ }^{15}$ Our group and others have reported that HBV
DNA is preferentially integrated into or in the vicinity of the human telomerase reverse transcriptase (hTERT) gene in HCCs. ${ }^{15-18}$ In this report, we have performed a large scale analysis of cellular genes targeted by HBV-DNA integration to identify cancer related genes and recurrent sites of viral integration.

\section{METHODS}

\section{Study population}

The study population consisted of 50 cases of HBV positive HCCs obtained by surgical resection. Ten additional previously published viral-host junctions were taken into account for a better interpretation of results. Pathological analyses of adjacent non-tumorous tissues showed minimal liver change in four cases, chronic hepatitis in 15 cases, liver cirrhosis in 27 cases while for 14 cases no information was available (table 1). The study protocol conformed to the ethical guideline of the Declaration of Helsinki (1975). All patients or their relatives provided written informed consent, and the ethics committee of the Kyoto Prefectural University of Medicine approved all aspects of the study.

\section{Sample preparation}

DNA was extracted from liver tissues using the "G'NOME DNA isolation kit" (BIO 101, Joshua Way, California, USA), according to the manufacturer's instructions. All samples were stored at $-80^{\circ} \mathrm{C}$ and carefully handled to avoid contamination by other nucleic acids.

Abbreviations: $\mathrm{HCC}$, hepatocellular carcinoma; $\mathrm{HBV}$, hepatitis B virus; hTERT, human telomerase reverse transcriptase; WHV, Woodchuck hepatitis virus; HPV, human papillomavirus; PCR, polymerase chain reaction; PDGF, platelet derived growth factor; MLL, mixed lineage leukaemia; APCL, adenomatous poliposis coli-like; MGMT, $\mathrm{O}^{6}$-methylguanine DNA methyltransferase 


\begin{tabular}{|c|c|c|c|c|c|c|c|c|}
\hline \multirow[b]{2}{*}{ Code } & \multirow{2}{*}{$\begin{array}{l}\text { Age } \\
\text { (y) }\end{array}$} & \multirow[b]{2}{*}{ Sex } & \multicolumn{4}{|c|}{ Serological markers } & \multirow[b]{2}{*}{ Liver tissue } & \multirow[b]{2}{*}{ Reference } \\
\hline & & & $\mathrm{HBsAg}$ & Anti-HBs & Anti-HBc & Anti-HCV & & \\
\hline $2 \mathrm{~A}$ & 68 & $\mathrm{~F}$ & + & - & + & - & MLC & \\
\hline $3 A$ & 44 & M & + & - & + & + & $\mathrm{CH}$ & \\
\hline $5 \mathrm{~A}$ & 59 & M & + & - & + & - & LC & \\
\hline 7 & 48 & M & + & - & + & - & $\mathrm{NI}$ & \\
\hline 8 & 48 & M & + & - & + & - & $\mathrm{NI}$ & \\
\hline $8 \mathrm{~A}$ & 57 & M & + & - & + & - & LC & \\
\hline 9 & 47 & M & + & - & + & - & $\mathrm{CH}$ & \\
\hline 10 & 38 & M & + & - & + & - & LC & \\
\hline $10 \mathrm{~A}$ & 67 & $\mathrm{~F}$ & + & - & + & - & LC & \\
\hline $11 \mathrm{~A}$ & 62 & $\mathrm{~F}$ & + & - & + & - & $\mathrm{LC}$ & \\
\hline $12 \mathrm{~A}$ & 63 & M & + & - & + & - & $\mathrm{CH}$ & \\
\hline 13 & 48 & M & + & - & + & - & LC & \\
\hline $13 \mathrm{~A}$ & 53 & M & + & - & + & - & $\mathrm{CH}$ & \\
\hline 14 & 26 & M & + & - & + & - & $\mathrm{CH}$ & \\
\hline 15 & 48 & M & + & - & + & - & $\mathrm{CH}$ & \\
\hline $16 \mathrm{~A}$ & 49 & M & + & - & + & - & $\mathrm{CH}$ & \\
\hline 37 & 66 & $\mathrm{~F}$ & + & - & + & - & $\mathrm{NI}$ & \\
\hline 41 & 42 & M & + & - & + & - & LC & \\
\hline 43 & 57 & M & - & - & + & + & LC & \\
\hline 49 & 69 & $\mathrm{~F}$ & + & - & + & - & $\mathrm{NI}$ & \\
\hline 100 & 26 & $\mathrm{~F}$ & + & - & + & - & MLC & \\
\hline 101 & 36 & $\mathrm{~F}$ & + & - & + & - & $\mathrm{CH}$ & \\
\hline F2T1-4 & 47 & M & + & - & + & - & LC & \\
\hline F2T1-5 & 82 & M & + & - & + & - & $\mathrm{CH}$ & \\
\hline F2T2-1 & 51 & M & + & - & + & - & LC & \\
\hline $\mathrm{F} 2 \mathrm{~T} 2-2$ & 43 & M & + & - & + & + & LC & \\
\hline $\mathrm{F} 2 \mathrm{~T} 2-5$ & 66 & M & + & - & + & - & $\mathrm{CH}$ & \\
\hline T2-6 & 78 & M & + & - & + & + & LC & \\
\hline MN3-3 & 27 & $\mathrm{~F}$ & + & - & + & - & $\mathrm{CH}$ & \\
\hline TAT6-4 & 69 & $\mathrm{~F}$ & + & - & + & - & LC & \\
\hline TAN7-3 & 57 & M & + & - & + & - & LC & \\
\hline $\mathrm{TN}-2$ & 52 & M & + & - & + & - & LC & \\
\hline $\mathrm{TN}-3$ & 47 & M & + & - & + & - & $\mathrm{CH}$ & \\
\hline$\Pi \pi-1$ & 60 & M & + & - & + & - & LC & \\
\hline $54 \mathrm{~T}$ & 29 & $\mathrm{~F}$ & + & - & + & - & MLC & \\
\hline $63 \mathrm{~T}$ & 65 & M & + & - & + & - & MLC & \\
\hline $77 T$ & 53 & M & + & - & + & - & $\mathrm{CH}$ & \\
\hline $83 \mathrm{~T}$ & 49 & M & + & - & + & - & LC & \\
\hline $86 \mathrm{~T}$ & 65 & M & - & + & + & + & $\mathrm{CH}$ & \\
\hline $95 \mathrm{~T}$ & 17 & M & + & - & + & - & LC & \\
\hline FR2 & 65 & M & + & - & + & - & LC & \\
\hline FR3 & 71 & M & + & - & + & - & LC & \\
\hline FR7 & 45 & M & + & - & + & - & LC & \\
\hline SAl & 48 & M & + & - & + & - & $\mathrm{CH}$ & \\
\hline SA2 & 53 & M & + & - & + & - & LC & \\
\hline SA5 & 59 & M & + & - & + & - & LC & \\
\hline GR1 & 62 & M & - & + & - & - & LC & \\
\hline GR2 & 71 & M & + & - & + & - & LC & \\
\hline GR3 & 66 & M & + & - & + & - & LC & \\
\hline GR10 & 69 & M & + & - & + & - & LC & \\
\hline BB3 & $\mathrm{NI}$ & $\mathrm{NI}$ & $\mathrm{NI}$ & $\mathrm{NI}$ & $\mathrm{NI}$ & $\mathrm{NI}$ & $\mathrm{NI}$ & Quade $^{19}$ \\
\hline BE5REV & $\mathrm{NI}$ & $\mathrm{NI}$ & $\mathrm{NI}$ & $\mathrm{NI}$ & $\mathrm{NI}$ & $\mathrm{NI}$ & $\mathrm{NI}$ & Quade 19 \\
\hline $3 \mathrm{~T}-470$ & $\mathrm{NI}$ & $\mathrm{NI}$ & $\mathrm{NI}$ & $\mathrm{NI}$ & $\mathrm{NI}$ & $\mathrm{NI}$ & $\mathrm{NI}$ & Tsuei $^{20}$ \\
\hline $669 \mathrm{Hb}$ & $\mathrm{NI}$ & $\mathrm{NI}$ & $\mathrm{NI}$ & $\mathrm{NI}$ & $\mathrm{NI}$ & $\mathrm{NI}$ & $\mathrm{NI}$ & Tsuei $^{21}$ \\
\hline PP5T & $\mathrm{NI}$ & $\mathrm{NI}$ & $\mathrm{NI}$ & $\mathrm{NI}$ & $\mathrm{NI}$ & $\mathrm{NI}$ & $\mathrm{NI}$ & $\operatorname{Pineau}^{22}$ \\
\hline PP7T & $\mathrm{NI}$ & $\mathrm{NI}$ & $\mathrm{NI}$ & $\mathrm{NI}$ & $\mathrm{NI}$ & $\mathrm{NI}$ & $\mathrm{NI}$ & Pineau $P^{22}$ \\
\hline $1217 \mathrm{Ha}$ & $\mathrm{NI}$ & $\mathrm{NI}$ & $\mathrm{NI}$ & $\mathrm{NI}$ & $\mathrm{NI}$ & $\mathrm{NI}$ & $\mathrm{NI}$ & Tsuei $^{21}$ \\
\hline 13T-198 & $\mathrm{NI}$ & $\mathrm{NI}$ & $\mathrm{NI}$ & $\mathrm{NI}$ & $\mathrm{NI}$ & $\mathrm{NI}$ & $\mathrm{NI}$ & Tsuei $^{20}$ \\
\hline HCl707-1 & $\mathrm{NI}$ & $\mathrm{NI}$ & $\mathrm{NI}$ & $\mathrm{NI}$ & $\mathrm{NI}$ & $\mathrm{NI}$ & $\mathrm{NI}$ & Yaginuma $^{23}$ \\
\hline$\lambda \mathrm{YH} 16$ & $\mathrm{NI}$ & $\mathrm{NI}$ & $\mathrm{NI}$ & $\mathrm{NI}$ & $\mathrm{NI}$ & $\mathrm{NI}$ & $\mathrm{NI}$ & Matsumoto $^{24}$ \\
\hline
\end{tabular}

\section{Detection of viral-host junctions}

A polymerase chain reaction (PCR) based technique (AluPCR) was employed using specific primers to human Alu sequences and to HBV sequences to efficiently amplify viralhost junctions, as previously described..$^{25}$ We also used additional primer sets and a schematic view of this PCR strategy is illustrated in fig 1 and supplementary table 1 (supplementary table 1 can be viewed on the Gut website at http://www.gutjnl.com/supplemental). Amplified PCR products were analysed by electrophoresis on $1.0 \%$ agarose gel and transferred to a Hybond- $\mathrm{N}^{+}$nylon membrane (Amersham-Pharmacia, Buckinghamshire, UK). To prepare a full length HBV probe, the total HBV genome was amplified according to the method of Günther and colleagues, ${ }^{27}$ and the HBV specific bands were detected by hybridisation with a DIG labelled probe (Roche, Mannheim, Germany).

\section{Direct sequencing}

The amplified viral-host junctions were analysed by sequencing using the dideoxy chain termination method. DNA was 
A

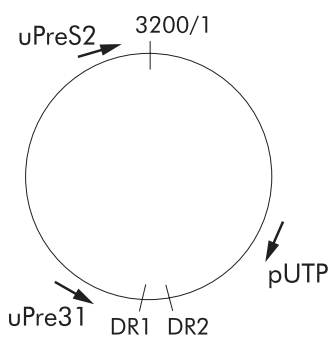

B

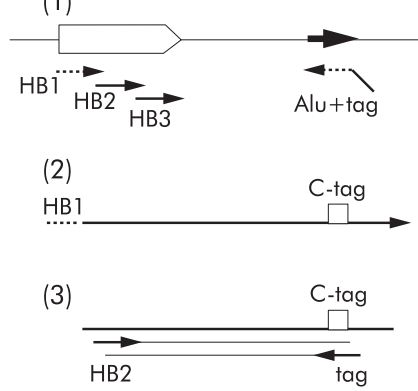

Figure 1 (A) Localisation on the hepatitis B virus (HBV) genome of the primers used in this study. Open circle represents the total HBV sequence, nucleotide 3200/1, DR1, and DR2 indicate numbering from the hypothetical EcoRI site (HBV subtype adw and accession number V00866 were used as reference sequences), ${ }^{28}$ direct repeat 1 , and direct repeat 2, respectively. Arrows represent $\mathrm{HB} 1$ primers (HBV preS2/S (uPreS2), HBV X (pUTP), and HBV core region (uPre31), respectively). (B) Schematic protocol for amplification of the viral-host junction. Technical details of the procedure have been previously reported. ${ }^{15} 16$ (1) Small arrows represent primers. Primers represented as broken arrows are synthesised with DUTP instead of DTTP and can be denatured by uracil DNA glycosylase (UDG) treatment. The Alu specific primer has a $5^{\prime}$ tag sequence (Alu+tag). (2) After the tag introducing polymerase chain reaction (PCR), this PCR product is comprised of HBV sequence, cellular franking sequence, and newly synthesised complementary to the tag sequence (cTag), which is indicated by a rectangle. (3) The primers synthesised with dUTP are denatured by UDG and further amplification is performed by HB2 and tag primer, then a second PCR is carried out using HB3 and the Alu tag primer.

purified with an Easy trap kit (Takara, Otsu, Japan) and subjected to sequencing using the Prism Taq DyeDeoxy Terminator cycle sequencing kit (Applied Biosystems Inc., Foster City, California, USA), according to the manufacturer's instructions. The sequencing products were precipitated with ethanol and then analysed by electrophoresis with a 377 Prism DNA sequencer (Applied Biosystems Inc.).

\section{RESULTS}

We utilised a modified Alu-PCR method using primers specific to HBV-X and to HBV-preS2/S and core regions. Collectively, 68 viral-host junctions from 60 specimens were obtained. Fifty eight of 68 viral-host junctions were detected by Alu-PCR and 10 junctions which had already been published were detected by conventional methods. Fifty six of 58 viral-host junctions were obtained with the HBV-X primer, one was obtained with the HBV-S primer, and one was obtained with the HBV core primer. The short viral and cellular sequences at the 68 junctions are shown in the right part of supplementary fig 1 (supplementary fig 1 can be viewed on the Gut website at http://www.gutjnl.com/supplemental). The cellular flanking sequences were assessed using the BLAST search system. Seven cellular flanking sequences were repetitive or unidentified sequences and 61 were cellular gene sequences, including 17 sequences potentially encoding unknown proteins (table 2 and supplementary table 2supplementary table 2 can be viewed on the Gut website at http://www.gutjnl.com/supplemental). These cellular sequences were divided into three groups (table 2): (1) genes already known to be involved in carcinogenesis: 15 genes ( 17 cases); (2) genes already known and/or fully characterised but not previously known to be involved in carcinogenesis: 25 genes; and (3) unknown open reading frames or genes belonging to a known gene family but not functionally characterised: 19 cases, eight of which had characters or significant motifs similar to those described in other cellular genes.
Orientation of the HBV genome ORF was either the same or opposite to the cellular gene orientation, and HBV DNA integration was found either in the vicinity of or into the cellular gene (supplementary fig l-supplementary fig 1 can be viewed on the Gut website at http://www.gutjnl.com/ supplemental). Recurrent HBV integration was found in the hTERT gene (three cases). We also found two recurrent target pathways: calcium signalling related genes (four genes: sarco/endoplasmic reticulum calcium ATPase l (SERCAl), inositol triphosphate receptor type I (IP3R1), inositol 1,4,5triphosphate receptor type 2 (ITPR2), and SPARC related modular calcium binding 1 (SMOC1)), and 60s ribosomal protein-like encoding genes (three genes: L7a, L14, and L17). Moreover, in two cases, HBV was integrated into genes belonging to the same gene family: platelet derived growth factor family (PDGF) (two genes: PDGF receptor beta and PDGF beta), and mixed lineage leukaemia family (MLL) (two genes: MLL2 and MLL4). Additionally, five apoptosis associated genes (hTERT, thyroid hormone associated protein 150 alpha (TRAP $150 \alpha$ ), scavenger receptor class A member 3 (SCARA3), mitogen associated protein kinase l (MAPKl), BCL2-like 2 (BCL2L2)) were targeted by HBV. Our preliminary data had shown that TRAP $150 \alpha$ is involved in the control of apoptosis (Murakami Y et al, in preparation). Two tumour suppressor genes were also found at the HBV integration site: adenomatous poliposis coli-like (APCL) and $\mathrm{O}^{6}$-methylguanine DNA methyltransferase (MGMT). Concerning viral integrations into the hTERT gene, orientation of the HBV DNA was opposite to that of the hTERT gene in all three cases: HBV being integrated $10.8 \mathrm{~kb}$ upstream to the promoter, $0.3 \mathrm{~kb}$ downstream, and $16 \mathrm{~kb}$ downstream to the gene, respectively (fig 2). In all of the other genes, HBV DNA orientation and position into or close to the open reading frame were variable. The chromosomal localisation of viral integration was distributed on all chromosomes except chromosome 13, X, and Y (fig 3).

\section{DISCUSSION}

Our study demonstrates that a large scale analysis of HBV DNA integration sites in liver cancer enables identification of several cancer related genes and pathways. Most of the viral integration sites are located in the vicinity of cellular genes or inside the coding sequences. This situation is susceptible to activation of expression of proto-oncogenes or inactivation of tumour suppressor genes as a result of viral insertion. The inserted viral sequences are sometimes located immediately upstream or downstream of the target gene. In some cases, integration is quite distant to the target genes but this is not inconsistent with an impact of HBV DNA on expression of the target gene, as shown for the win locus targeted by WHV integration in woodchuck liver cancers. ${ }^{29}$ In addition, viral integration and human chromosomal translocations can disrupt gene expression over hundreds of kilobases. Therefore, we cannot exclude some candidate target genes because of the distance between the integration site and target genes. ${ }^{130} \mathrm{~A}$ recent report on 14 cases of HBV-DNA integration showed that most cellular flanking sequences are repetitive sequences but identification of longer sequences flanking the HBV-DNA integration site would have allowed identification of a higher number of unique sequences, which are needed to accurately locate the HBV integration site in the human genome. ${ }^{31}$

Viral integration into the cellular genome has been thought to occur randomly ${ }^{2}$ but our study and other laboratory studies have shown that hTERT is a recurrent site of viral integration. ${ }^{15}{ }^{18}$ Our present study, by identifying five gene families recurrently targeted by the viral genome, supports the view of recurrent targeting of genes involved in cell signalling and growth control: hTERT, PDGF receptor, 
Table 2 Target genes searched by viral insertion

\begin{tabular}{|c|c|c|c|}
\hline Code & $\begin{array}{l}\text { Gene/type of } \\
\text { sequence }\end{array}$ & Full name of gene and protein & Function/protein family \\
\hline \multicolumn{4}{|c|}{ Cancer associated genes } \\
\hline $2 A-1$ & hTERT & Human telomerase reverse transcriptase & Telomerase regulation \\
\hline $2 \mathrm{~A}-2$ & TACC-1 & Transforming acedic coiled-coil containing protein 1 & Proto-oncogenes \\
\hline $5 \mathrm{~A}-1$ & IRF2 & Interferon regulatory factor 2 & Interferon regulation \\
\hline 7 & MUC16 & Mucin 16 & $\begin{array}{l}\text { Transmembrane region and tyrosine } \\
\text { phosphorylation site }\end{array}$ \\
\hline $11 \mathrm{~A}$ & PDGFRB & $\begin{array}{l}\text { Platelet derived growth factor receptor beta precursor; } \\
\text { beta platelet derived growth factor receptor }\end{array}$ & Growth factor \\
\hline 37 & APCL & Adenomatous polyposis coli-like & APC homology \\
\hline 41 & GA & Liver mitochondrial glutaminase/breast cell glutaminase & Glutaminase proteins/proto-oncogene \\
\hline F2T1-4 & MLL2 & Myeloid/lymphoid or mixed lineage leukaemia 2 & Transcriptional regulator \\
\hline F2TI-5 & MGMT & O-6-methylguanine-DNA methyltransferase & DNA reparation \\
\hline $54 \mathrm{~T}$ & p84 & Nuclear matrix protein $\mathrm{p} 84$ & Nuclear matrix protein \\
\hline 83T-A & hTERT & Human telomerase reverse transcriptase & Telomerase regulation \\
\hline $86 \mathrm{~T}$ & SERCA1 & Sarco/endoplasmic reticulum calcium ATPase 1 & Calcium regulation \\
\hline GR2 & MAPKI & Mitogen activated protein kinase 1 & Protein kinase \\
\hline TAN7-3 & EVER2 & Epidermodysplasia verruciformis 2 & Integral membrane protein located in the ER \\
\hline BB3 & hTERT & Human telomerase reverse transcriptase & Telomerase regulation \\
\hline $3 \mathrm{~T}-470$ & PDGFB & $\begin{array}{l}\text { Platelet derived growth factor beta polypeptide (simian sarcoma } \\
\text { viral ( } v \text {-sis) oncogene homologue) }\end{array}$ & Growth factor \\
\hline \multicolumn{4}{|l|}{ Cellular genes } \\
\hline $8 \mathrm{~A}$ & FN1 & Fibronectin 1 & $\begin{array}{l}\text { Cell adhesion, morphology, and surface } \\
\text { architecture }\end{array}$ \\
\hline $10 \mathrm{~A}$ & NEDD4L & $\begin{array}{l}\text { Ubiquitin-protein ligase NEDD4-like; neural precursor cell } \\
\text { expressed, developmentally downregulated gene } 4 \text {-like }\end{array}$ & Ubiquitin ligase \\
\hline $10 \mathrm{~S}$ & IRAK2 & Interleukin 1 receptor associated kinase 2 & Interleukin regulation \\
\hline $12 \mathrm{~A}-1$ & NCF1 & Neutrophil cytosolic factor 1 & NADPH oxidase \\
\hline $12 \mathrm{~A}-2$ & ITPR2 & Inositol 1,4,5-triphosphate receptor, type 2 & Calcium regulation \\
\hline 14 & $\mathrm{CCT}$ & Chaperonin containing TCPI, subunit 8 (theta) & Cell cycle regulation \\
\hline 15 & TCEA3 & Transcription factor Sll related protein 4 & $\begin{array}{l}\text { Binds to RNA polymerase II and stimulates } \\
\text { nuclease activity }\end{array}$ \\
\hline $16 \mathrm{~A}$ & SCARA3 & Scavenger receptor class $A$, member 3 & Apoptotic regulation \\
\hline 100 & TRAP150 & Thyroid hormone associated protein 150 alpha & Co-activator of nuclear receptor \\
\hline 101 & GCHFR & GTP cyclohydrolase I feedback regulatory protein & $\begin{array}{l}\text { Key enzyme of tetrahydrobiopterin } \\
\text { biosynthesis }\end{array}$ \\
\hline $\mathrm{F} 2 \mathrm{~T} 2-5$ & BIRC3 & Baculoviral IAP repeat-containing 3 & Apoptosis inhibitor \\
\hline $\mathrm{T} 2-6$ & CHML & Choroideraemia-like (Rab escort protein 2) & Geranylgeranylation of most Rab proteins \\
\hline $\mathrm{TN}-2$ & ORMI & Orosomucoid 1 & Ubiquitin protein \\
\hline $\mathrm{TN}-3$ & BCL2L2 & BCL2-like 2 & Apoptotic regulation \\
\hline$\pi-1$ & RAl17 & Retinoic acid induced gene 17 & Co-regulator of androgen receptor \\
\hline $63 \mathrm{~T}$ & CASPR3 & Cell recognition molecule CASPR3 & Cell differentiation \\
\hline $77 T$ & hMCM8 & Human minichromosome maintenance protein 8 & Cell cycle regulation \\
\hline 83T-B & SFXN5 & Sideroflexin 5 & Rabl1-interacting protein \\
\hline $95 \mathrm{~T}$ & NTRK2 & Neutrophic tyrosine kinase receptor type 2 & Receptor for neurotrophic factor \\
\hline FR2 & SMOC1 & SPARC related modular calcium binding 1 & Calcium regulation \\
\hline GRI & $\mathrm{KIF} 3 \mathrm{C}$ & Kinesin family member $3 C$ & Kinesin family \\
\hline SAl & ST3GAL IV & Alpha2,3-sialyltransferase & Cell differentiation \\
\hline SA2 & IP3R 1 & Inositol triphosphate receptor type 1 & Calcium regulation \\
\hline $\mathrm{HC1707-1}$ & GRID2 & Glutamate receptor, ionotropic, delta 2 & lonotropic glutamate receptor \\
\hline MN3-3 & PDE6D & Phosphodiesterase 6D, cGMP-specific, rod, delta & Phosphodiesterase \\
\hline \multicolumn{4}{|c|}{ Unknown proteins } \\
\hline $5 \mathrm{~A}-2$ & FU23027 & Hypothetical protein FU23027 & ND \\
\hline 8 & LOC374740 & LOC374740 & ND \\
\hline 9S & LOC254277 & Similar to eukaryotic translation elongation factor 1 alpha 2 & $\begin{array}{l}\text { Binding of aminoacyl-tRNAs to } 80 \mathrm{~S} \\
\text { ribosomes }\end{array}$ \\
\hline $10 \mathrm{~L}$ & FU20850 & FL20850 & ND \\
\hline $13 \mathrm{~A}$ & LOC253820 & Similar to MEGF6 (Rattus norvegicus) & EGF-like domain \\
\hline 43 & LOC402235 & Similar to Acl 147 & Rho-GEF protein and ligand for sAnk1 \\
\hline 49 & LOC285866 & LOC285866 & ND \\
\hline F2T2-1 & LOC169831 & Similar to Sorting nexin 7 & $\begin{array}{l}\text { Receptor family with phox homology (PX) } \\
\text { domain }\end{array}$ \\
\hline F2T2-2 & LOC342193 & $\begin{array}{l}\text { Similar to transcriptional co-repressor Sin3A; transcriptional } \\
\text { regulator, SIN3A (yeast) }\end{array}$ & $\begin{array}{l}\text { Transcription of the gene encoding luteinising } \\
\text { hormone receptor }\end{array}$ \\
\hline TAT6-4 & LOC376426 & $\begin{array}{l}\text { Similar to v-erb-a avian erythroblastic leukaemia viral oncogene } \\
\text { homologue } 2 \text {-like }\end{array}$ & Proto-oncogene \\
\hline FR3 & LOC222792 & Similar to 60 S ribosomal protein L7A (Surfeit locus protein 3) & ND \\
\hline FR7 & FR7 & FR7 gene & ND \\
\hline GR2s & LOC91948 & LOC91948 & ND \\
\hline GR3 & LOC342670 & $\begin{array}{l}\text { Similar to putative protein, nematode specific (Caenorhabditis } \\
\text { elegans) }\end{array}$ & ND \\
\hline SA5 & LOC204740 & Similar to hypothetical protein DKFZp434F1017 & ND \\
\hline $669 \mathrm{Hb}$ & LOC116166 & Similar to sorbitol dehydrogenase (L-iditol 2-dehydrogenase) & Catalyses the interconversion of polyols \\
\hline PP5T & LOC221026 & Similar to 60 S ribosomal protein L17 (L23) & ND \\
\hline PP7T & FU39630 & Hypothetical protein $1-107$ & ND \\
\hline
\end{tabular}




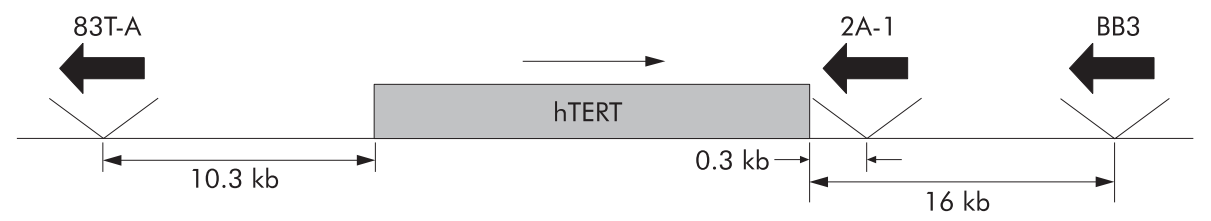

Figure 2 Hepatitis B virus (HBV) DNA integration in the human telomerase reverse transcriptase (hTERT) gene. The shaded box is the hTERT gene, the bold arrows indicate the position and orientation of the inserted viral sequence, and the thin arrows indicate the orientation of the hTERT gene. The distance between the ATG or stop codon and the HBV integration site is indicated (kb). The letters on the top of the bold arrow indicate the hepatocellular carcinoma code, as reported in table 1.

calcium signalling related genes, MLL, and 60s ribosomal protein genes. hTERT gene expression has been found to be increased in HCCs. ${ }^{32}$ RNA expression of MLL was found to be amplified in several tumours, including HCC. ${ }^{33-37}$ Recently, Saigo et al found that a HBX-MLL fusion protein was dominantly expressed in three HCC tissues and chromosomal translocation was also observed in these cases (personal communication). A distinct group of genes includes PDGF-B, APCL, and MGMT, having a p53 dependent tumorigenic effect. $^{38}{ }^{39}$ Moreover, the PDGF-B/PDGF-R system has a critical function for pericyte recruitment to tumour vessels. ${ }^{37}$ APCL may be involved in the p53/Bcl2 linked pathway of cell cycle progression and cell death. ${ }^{40}$ MGMT hypermethylation has been involved in pharmacoepigenomics: methylated tumours are more sensitive to the killing effects of alkylating drugs used in chemotherapy. ${ }^{41}$ Another gene group includes calcium signalling genes. A previous study led to the discovery of new truncated and hybrid HBx-SERCAl proteins involved in the control of apoptosis..$^{42}$ Calcium homeostasis is also modified by HBV-X protein, which acts on calcium extrusion mechanisms, playing an important role in the control of HBX related apoptosis. ${ }^{43}$ We found that HBV targets ribosomal protein L7a, L14, and L17 genes. In vivo, constitutive expression of L7 has been found to induce cell cycle arrest, ${ }^{44}$ and trk- $2 \mathrm{~h}$ oncogene, which derived from the human breast cancer cell line MDA-MB231, encoded a $44 \mathrm{kDa}$ phosphoprotein exhibiting tyrosine protein kinase activity and the $\mathrm{N}$ terminal 41 amino acids were derived from the $\mathrm{N}$ terminal of human ribosomal large unit $\mathrm{L7a}{ }^{45}$
Overexpression of the ribosomal protein L36a has been associated with tumour cell proliferation in HCCs. ${ }^{46}$

Our group has recently shown that viral integration and cellular DNA genetic rearrangements were observed in patients with acute hepatitis. ${ }^{26}$ These genetic changes have also been observed in the liver of patients with HBV chronic hepatitis (not during the latent phase).$^{47}$ Acquired transforming activity of mutated cellular and viral proteins, including chimeric HBV cellular proteins, encoded following HBV integration have already been reported in previous studies. (a) In the viral genome, both the $3^{\prime}$ truncated HBV X and preS2/S gene products may exhibit oncogenic activity. Most new open reading frames created in HCCs by the HBV DNA integration derive from the $3^{\prime}$ truncated HBV-X sequence fused in frame to the cellular flanking sequence. These viral onco-proteins act by transactivating genes that regulate cellular growth. While the whole HBx protein may induce apoptosis through mitochondrial dysfunction and caspase activation $^{43}$ and suppress the transforming activity of ras and myc oncogenes, C terminally truncated HBx proteins have been shown to promote the transforming activity of ras and myc oncogenes. ${ }^{48}$ The HBV genome includes enhancer elements capable of activating heterologous promoters in a position and orientation independent manner. ${ }^{49}$ Moreover, a mechanism of viral enhancer insertion has been reported in many examples of retroviral integration, ${ }^{50}{ }^{51}$ as well as in WHV insertional mutagenesis. ${ }^{52}$ (b) In the cellular genome, hyperexpression and aberrant transcription of hTERT, ${ }^{16}$ truncated transcription of hMCM $8,{ }^{53}$ and hybrid viral/cellular

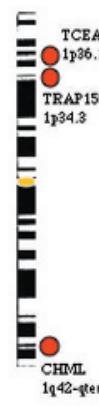

Fig 3
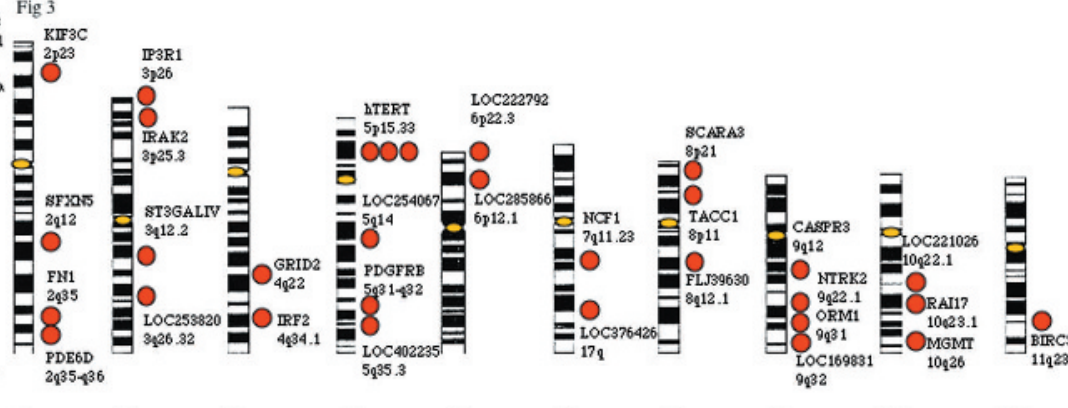

1

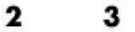

45

6

7

8

9

10

11

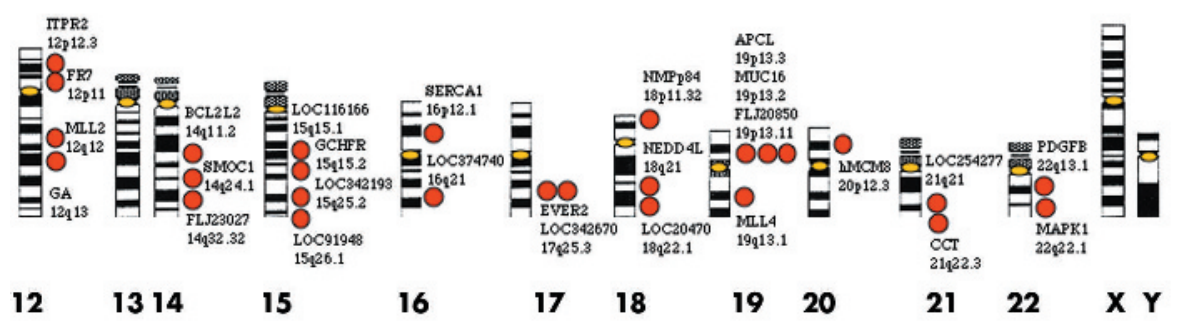

Figure 3 Distribution of the viral integration sites on the chromosome map. Red spots indicate viral integration sites. The names and chromosomal localisations of the genes are also indicated. 
transcription of SERCAl, FR7, and cyclin A have been previously reported $^{14254}$ and, in some analysed cases, ${ }^{55}$ shown to have transforming activity. The different patterns of HBV integration are all susceptible to modified expression of the target cellular genes. These mutagenic effects related to viral insertion may play an important role in liver carcinogenesis.

Taken together, our results suggest the following hypothesis of tumour development. Firstly, viral integration occurring during the acute phase of infection induces genetic changes in the target cellular gene. Secondly, the oncogenic activity of the cellular and viral genes modified by the viral integration may provide the cells harbouring the HBV DNA integration with a selective growth advantage (over viral propagation) during the chronic phase of the infection. Increasing accumulation of genetic changes during liver cell proliferation may finally lead to hepatocarcinogenesis.

In conclusion, we have found that all of the 61 genes identified at the HBV DNA integration site are at risk of being involved in the control of cell proliferation and/or survival, being likely to play a role in the development of liver cancer. HBV insertional tagging provides a new tool for identifying human cancer related genes. This study has shown the high prevalence of $\mathrm{HBV}$ integration in genes involved in cell signalling. Our results have taken advantage of the recent progress achieved in the field of human genome sequencing. We propose the view that viral insertion induces the first genetic change in liver tumorigenesis and that genes targeted by viral integration may play an important role in hepatocarcinogenesis.

\section{ACKNOWLEDGEMENTS}

The authors are grateful to Professor Takashi Inamoto, Department of Gastroenterological Surgery, Kyoto University, and Professor Hisakazu Yamagishi, Department of Gastroenterological Surgery, Kyoto Prefectural University of Medicine, for providing the liver samples.

\section{Authors' affiliations}

Y Murakami*, Department of Gastroenterology, Fukui National Hospital, Fukui, Japan, and Department of Gastroenterology, Kyoto Prefectural University of Medicine, Kyoto, Japan

K Saigo, Second Department of Surgery, Chiba University, Chiba, Japan H Takashima, M Minami, T Okanove, Department of Gastroenterology, Kyoto Prefectural University of Medicine, Kyoto, Japan

C Bréchot, P Paterlini-Bréchot, Institut Pasteur/INSERM U-370, Paris, France

*Present address: Laboratory of Human Tumour Viruses, Department of Viral Oncology, Institute for Viral Research, Kyoto University, Kyoto, Japan. Kawahara-cho, Shogoin, Sakyo-ku, Kyoto 606-8507, Japan.

Conflict of interest: None declared.

\section{REFERENCES}

1 Suzuki T, Shen $\mathrm{H}$, Akagi $\mathrm{K}$, et al. New genes involved in cancer identified by retroviral tagging. Nat Genet 2002;32:166-74.

2 Brechot C, Gozuacik D, Murakami Y, et al. Molecular bases for the development of hepatitis B virus (HBV)-related hepatocellular carcinoma (HCC). Semin Cancer Biol 2000;10:211-31.

3 Nagaya T, Nakamura T, Tokino T, et al. The mode of hepatitis B virus DNA integration in chromosomes of human hepatocellular carcinoma. Genes Dev 1987; 1:773-82.

4 Yaginuma K, Kobayashi $\mathrm{H}$, Kobayashi M, et al. Multiple integration site of hepatitis $B$ virus DNA in hepatocellular carcinoma and chronic active hepatitis tissues from children. J Virol 1987;61:1808-13.

5 Robinson WS, Miller RH, Marion PL. Hepadnaviruses and retroviruses share genome homology and features of replication. Hepatology 1987;7:64-73S.

6 Hino O, Kitagawa T, Koike K, et al. Detection of hepatitis B virus DNA in hepatocellular carcinomas in Japan. Hepatology 1984;4:90-5.

7 Tokino T, Fukushige S, Nakamura T, et al. Chromosomal translocation and inverted duplication associated with integrated hepatitis B virus in hepatocellular carcinomas. J Virol 1987;61:3848-54.
8 Tokino T, Matsubara K. Chromosomal sites for hepatitis B virus integration in human hepatocellular carcinoma. J Virol 1991;65:6761-4.

9 Grisham JW. Molecular genetic alterations in primary hepatocellula neoplasms: hepatocellular adenoma, hepatocellular carcinoma, and hepatoblastoma. In: Coleman WB, Tsongalis GJ, eds. The molecular basis of human cancer. Totowa, New Jersey: Humana Press, 2001:269-346.

10 Seeger C, Mason WS. Hepatitis B virus biology. Microbiol Mol Biol Rev 2000:64:51-68.

11 Ferber MJ, Thorland EC, Brink AA, et al. Preferential integration of human papillomavirus type 18 near the c-myc locus in cervical carcinoma. Oncogene 2003;22:7233-42

12 Hsu T, Moroy T, Etiemble J, et al. Activation of c-myc by woodchuck hepatitis virus insertion in hepatocellular carcinoma. Cell 1988;55:627-35.

13 Fourel G, Trepo C, Bougueleret L, et al. Frequent activation of $\mathrm{N}$-myc genes by hepadnavirus insertion in woodchuck liver tumours. Nature 1990;347:294-8.

14 Gozuacik D, Murakami Y, Saigo K, et al. Identification of human cancerrelated genes by naturally occurring hepatitis B virus DNA tagging. Oncogene 2001:20:6233-40.

15 Paterlini-Brechot P, Saigo K, Murakami Y, et al. Hepatitis B virus-related insertional mutagenesis occurs frequently in human liver cancers and recurrently targets human telomerase gene. Oncogene 2003;22:3911-16.

16 Horikawa I, Barrett JC. cis-Activation of the human telomerase gene (hTERT) by the hepatitis B virus genome. J Natl Cancer Inst 2001;93:1171-3.

17 Lin T, Huang X, Gu J, et al. Long-term tumor-free survival from treatment with the GFP-TRAIL fusion gene expressed from the hTERT promoter in breast cancer cells. Oncogene 2002;21:8020-8.

18 Ferber MJ, Montoya DP, Yu C, et al. Integrations of the hepatitis B virus (HBV) and human papillomavirus (HPV) into the human telomerase reverse transcriptase (hTERT) gene in liver and cervical cancers. Oncogene 2003;22:3813-20.

19 Quade K, Saldanha J, Thomas H, et al. Integration of hepatitis B virus DNA through a mutational hot spot within the cohesive region in a case of hepatocellular carcinoma. J Gen Virol 1992;73:179-82.

20 Tsuei DJ, Chen PJ, Lai MY, et al. Inverse polymerase chain reaction for cloning cellular sequences adjacent to integrated hepatitis $B$ virus DNA in hepatocellular carcinomas. J Virol Methods 1994:49:269-84.

21 Tsuei DJ, Chang MH, Chen PJ, et al. Characterization of integration patterns and flanking cellular sequences of hepatitis B virus in childhood hepatocellular carcinomas. J Med Virol 2002;68:513-21.

22 Pineau P, Marchio A, Mattei MG, et al. Extensive analysis of duplicatedinverted hepatitis $B$ virus integrations in human hepatocellular carcinoma. J Gen Virol 1998;79:591-600.

23 Yaginuma K, Kobayashi H, Kobayashi M, et al. Multiple integration site of hepatitis $B$ virus DNA in hepatocellular carcinoma and chronic active hepatitis tissues from children. J Virol 1987:61:1808-13.

24 Matsumoto H, Yoneyama T, Mitamura K, et al. Analysis of integrated hepatitis $B$ virus DNA and cellular flanking sequences cloned from a hepatocellular carcinoma. Int J Cancer 1988;42:1-6.

25 Minami M, Poussin K, Brechot $C$, et al. A novel PCR technique using Aluspecific primers to identify unknown flanking sequences from the human genome. Genomics 1995;29:403-8.

26 Murakami Y, Minami M, Daimon Y, et al. Hepatitis B virus DNA in liver, serum, and peripheral blood mononuclear cells after the clearance of serum hepatitis B virus surface antigen. J Med Virol 2004;72:203-14.

27 Günther S, Li BC, Miska S, et al. A novel method for efficient amplification of whole hepatitis B virus genomes permits rapid functional analysis and reveals deletion mutants in immunosuppressed patients. J Virol 1995;69:5437-44.

28 Ono $\mathrm{Y}$, Onda $\mathrm{H}$, Sasada $\mathrm{H}$, et al. The complete nucleotide sequences of the cloned hepatitis B virus DNA; subtype adr and adw. Nucleic Acid Res 1983;11:1747-57

29 Fourel G, Tiollais P. Primary liver cancer: Etiological and progression factors. London: CRC Press, 1994:89-124.

30 Largaespada DA, Shaughnessy JD Jr, Jenkins NA, et al. Retroviral integration at the Evi-2 locus in BXH-2 myeloid leukemia cell lines disrupts $\mathrm{NF} 1$ expression without changes in steady-state Ras-GTP levels. J Virol 1995;69:5095-102.

31 Wang Y, Lau SH, Sham STJ, et al. Characterization of HBV integrants in 14 hepatocellular carcinomas: association of truncated $X$ gene and hepatocellular carcinogenesis. Oncogene 2004;23:142-8.

32 Horikawa I, Barrett JC. Transcriptional regulation of the telomerase hTERT gene as a target for cellular and viral oncogenic mechanisms. Carcinogenesis 2003;24:1167-76.

33 Tahara $\mathrm{H}$, Nakanishi $T$, Kitamoto $M$, et al. Telomerase activity in human liver tissues: comparison between chronic liver disease and hepatocellular carcinomas. Cancer Res 1995;55:2734-6.

34 Nakashio $\mathrm{R}$, Kitamoto $M$, Tahara $\mathrm{H}$, et al. Significance of telomerase activity in the diagnosis of small differentiated hepatocellular carcinoma. Int J Cancer 1997:74:141-7.

35 Curtis L, Li Y, Gerbault-Seureau M, et al. Amplification of DNA sequences from chromosome 19q13.1 in human pancreatic cell lines. Genomics 1998:53:42-55

36 Faretta M, Di Croce L, Pelicci PG. Effects of the acute myeloid leukemiaassociated fusion proteins on nuclear architecture. Semin Hematol $2001 ; 38: 42-53$

37 Ishii E, Kawasaki H, Isoyama K, et al. Recent advances in the treatment of infant acute myeloid leukemia. Leuk Lymphoma 2003:44:741-8.

38 Hesselager G, Uhrbom L, Westermark B, et al. Complementary effects of platelet-derived growth factor autocrine stimulation and p53 or Ink4a-Arf deletion in a mouse glioma model 1. Cancer Res 2003;63:4305-9.

39 Abramsson A, Lindblom P, Betsholtz C. Endothelial and nonendothelial sources of PDGF-B regulate pericyte recruitment and influence vascular pattern formation in tumors. J Clin Invest 2003;112:1142-51. 
40 Nakagawa $\mathrm{H}$ Koyama $\mathrm{K}$, Murata $\mathrm{Y}$, et al. $\mathrm{APCL}$ a central nervous systemspecific homologue of adenomatous polyposis coli tumor suppressor, binds to p53-binding protein 2 and translocates it to the perinucleus. Cancer Res 2000;60:101-5.

41 Esteller M, Herman JG. Generating mutations but providing chemosensitivity: the role of $0^{6}$-methylguanine DNA methyltransferase in human cancer. the role of $\mathrm{O}^{6}$-methylguanin

42 Chami M, Gozuacik D, Saigo K, et al. Hepatitis B virus-related insertional mutagenesis implicates SERCA1 gene in the control of apoptosis. Oncogene 2000; 19:2877-86

43 Chami M, Ferrari D, Nicotera P, et al. Caspase-dependent alterations of Ca2+ signaling in the induction of apoptosis by hepatitis $B$ virus $X$ protein. J Biol Chem 2003:278:31745-55.

44 Neumann F, Krawinkel U. Constitutive expression of human ribosomal protein $\mathrm{L} 7$ arrests the cell cycle in G1 and induces apoptosis in Jurkat T-lymphoma cells. Exp Cell Res 1997;230:252-61

45 Ziemiecki A, Muller RG, Fu XC, et al. Oncogenic activation of the human trk proto-oncogene by recombination with the ribosomal large subunit protein L7a. EMBO J 1990:9:191-6.

$46 \mathrm{Kim} \mathrm{JH}$, You KR, Kim IH, et al. Over-expression of the ribosomal protein L36a gene is associated with cellular proliferation in hepatocellular carcinoma. Hepatology 2004;39: 129-38.
47 Takada S, Gotoh Y, Hayashi S, et al. Structural rearrangement of integrated hepatitis $B$ virus DNA as well as cellular flanking DNA is present in chronically infected hepatic tissues. J Virol 2000;64:822-8.

48 Tu H, Bonura C, Giannini C, et al. Biological impact of natural $\mathrm{COOH}$ terminal deletions of hepatitis $B$ virus $X$ protein in hepatocellular carcinoma tissues. Cancer Res 2001;61:7803-10.

49 Fourel G, Couturier J, Wei Y, et al. Evidence for long-range oncogene activation by hepadnavirus insertion. EMBO J 1994;13:2526-34.

50 Payne GS, Bishop JM, Varmus HE. Multiple arrangements of viral DNA and an activated host oncogene in bursal lymphomas. Nature 1982;295:209-14.

51 Corcoran LM, Adams JM, Dunn AR, et al. Lymphomas in which the cellular myc oncogene has been activated by retroviral insertion. Cell 1984;37:113-22.

52 Buendia MA. Mammalian hepatitis B viruses and primary liver cancer. Semin Cancer Biol 1992;3:309-20.

53 Gozuacik D, Chami M, Lagorce D, et al. Identification and functional characterization of a new member of the human $\mathrm{Mcm}$ protein family: $\mathrm{hMcm} 8$. Nucleic Acids Res 2003;31:570-9.

54 Wang J, Chenivesse X, Henglein B, et al. Hepatitis B virus integration in a cyclin A gene in a hepatocellular carcinoma. Nature 1990:343:555-7.

55 Berasain C, Patil D, Perara E, et al. Oncogenic activation of a human cyclin A2 targeted to the endoplasmic reticulum upon hepatitis B virus genome insertion. Oncogene 1998;16:1277-88.

\section{EDITOR'S QUIZ: GI SNAPSHOT}

\section{Answer}

From question on page 1113

The barium enema showed free flow of barium from the rectum to the caecum with no colonic lesion. Barium is shown to reflux into the terminal ileum, which shows increased number and thickness of folds in keeping with the appearance of "jejunisation" (as shown in fig 2). The diagnostic procedure was a duodenal biopsy, which showed severe villous blunting and numerous intraepithelial lymphocytes consistent with coeliac disease.

Reversal of the normal fold character between the ileum and jejunum often occurs in coeliac disease. Whereas there are fewer jejunal folds per unit length, the number and thickness of the folds in the ileum increases (that is, "jejunisation of the ileum"). This is seen in our case due to reflux of the barium into the terminal ileum. This change is thought to be due to the ability of the ileum to assume functions normally performed by the jejunum, a process of adaptation.

doi: 10.1136/gut.2004.063339

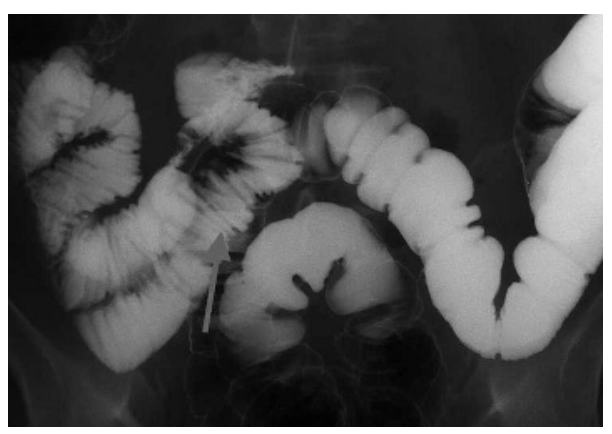

Figure 2 "Jejunisation" of the ileum. 